\title{
Rational Brain Transmutation Into Intuitive Brain Based on Neuroscience in Islamic Education
}

\author{
Rahmat Ryadhush Shalihin ${ }^{1}$, Suyadi $^{2}$, Desfa Yusmaliana ${ }^{3}$, Diyan Faturahman ${ }^{4}$ \\ 1,2,3,4 Universitas Ahmad Dahlan, Yogyakarta, Indonesia \\ "rahmatshalihin@yahoo.co.id
}

\begin{abstract}
The brain is one of the ultimate power and complicated operating systems work as a united and integrated area. Nevertheless, Islamic education study focused solely on logical, rational, and empirical brain processes. Besides, the brain also has the power of intuitive thinking whereas current findings show that intuition in the form of holistic can be superior for some reasons. In fact, people with this capability develop and retain their intuitive brain as important roles in strategic making decisions. Unfortunately, the typical type for both rational and intuitive brain has been separated and splitted personality in Islamic education study. Consequently, a logical person would be highly appreciated than an intuitive person. In this study, the researchers analyzed the rational and intuitive brain based on scientific models qualitative way, in the form of literacy research. The research results showed that the transmutation from rational to the intuitive brain through the point of fatigue to the Higher Order Thinking (C4-C6), SOLO Taxonomy, and Marzano's Taxonomy.
\end{abstract}

Keywords: Brain Transmutation; Intuitive; Neuroscience; Islamic Education

\section{Introduction}

Smart people's brain is the thinking capability of the brain which are not only recorded brain for some reason or the incident but also understanding the wisdom from incident that happen through senses part. As the first figure out, the implementation both of these brain's side occurs to the Prophet Moses and his meeting with "somebody who is more well-informed than himself" that replacing rational into intuitive (Q12: 11) [1]. Unfortunately, the main public thought it was a miracle phenomenon that science could not solve it. In fact, it was the crucial part revelation between the rational brain and intuitive brain in neuroscience outlook [2], [3] in this case, "somebody who is more well-informed" than Moses also known Prophet Khidr as a spiritual guide. Even though Prophet Moses has reached the rank of prophethood but he followed the Prophet Khidr whereabout personified picturesque relation as teacher and student. This event demonstrated the invisible capability (intuitive brain or kashf) and visible capability (rational brain) in order to gain knowledge [2], [4]. Although the history talking about prophetic characteristics, but this is also inspired Islamic education in the optimalization process of the intuitive brain in this paper. Unluckily, Islamic educational succeed more emphasized in the intellectual side rather than intelligence dimensional, particularly in intuitive intelligence.

Compared with intuition and imaginative thinking, Islamic education practice is still in state of split personality with logical and empirical priority [5]. Revealed that so far, creative 
imagination has not been greatly developed, and it is even considered a learning disorder. As results, Islamic education is no longer able to produce insan kamil, but a person who have splitted personality (separated entities). In fact, the transmutation of the brain was applied by Prophet Khidr who had reached out to the intuitive level in the prophetic aspect. Otherwise, most previous researchers about the rational brain and intuitive brain also still in the dichotomy area. The study about intuitive brain mostly in philosophism and Sufism, also known as emanation or revelation based on normative ways and god's approach. Inversely, the study about emanation has not been analyzing based on a scientific approach, especially in Islamic education and neuroscience perspective. Therefore, this study has hight urgencies to integrated both of the brain's side to prevent the domination one of the brain's works based on neuroscience [6]. The transmutation both of this brain part in Islamic education with the development of reasoning from teacher and student also tend to be balanced in their lives aspects as the dual-process approaches [7]. In the end, the transformation attempts to provide the typology Islamic education learning style and processes in order to increase student's thought and lead to effective decisions [8] through the Higher Order Thinking Skills (HOTS) in various taxonomies by the experts.

The brain as the Central Nervous System (CNS) consists of two parts of the hemisphere (neocortex) [9], namely the left hemisphere and the right hemisphere. Each one of these parts has a different processing system and information operation. The left hemisphere is specialized in verbal purposes, praxis patterns, and calculi skills, while the right hemisphere is specialized for processing the visual information (complex shapes and structures, non-verbal thinking and sounds, and facial recognition) [10]. Allinson and Hayes (1996) mentioned that the left hemisphere works in an intuition perspective and the right hemisphere works in analysis perspective [11]. However, the General Decision-making Style Inventory (GDMS) developed by Bruce and Scoot (1995) found the rational and intuitive works in independent ways. Nevertheless, recent study has found that both of this side works in the integrative pattern in the form of decisions-making styles [11]. In the neuroscience perspective, the left hemisphere process of critical thinking and the right hemisphere process of creative thinking. Correlations among both of the hemispheres can bring out the high potentials to be intelligent or intuitive brain [2] wherein depends on the way of thinking in order to process information and solving the problems of the human brain. Functional between the two hemispheres are working in relatively when triggered by specific stimuli [12], [13]. Understanding the two hemisphere could eventually lead to the new patterns to transforming the skills in the education system and produces progressive outcoming.

\section{Methodology}

This research uses descriptive analysis with a literature study approach

\section{Result and Discussion}

\section{a. Rational brain}

Generally, anyone has a specialization that allows him becomes a rational person (rationalism) who analyzes information throughout particularization (step-by-step pattern) or becomes typical of person who processes the data in comprehensive and integrated ways by minimizing the subjectivity aspects [7]. The ability of human beings in a rational perspective 
is seen as the highest achievement. Thus, the rational person takes ideas, decisions, and knowledge-based on reason from five senses and makes that experience for an incentive of mind power. The way of thinking rational brain derived from logical, sequential, rule-based [14], and linear activity whereas according to the regular tasks, such as verbal expression, writing, listening, reading, phonetics, and symbolism. However, Simon (1993) founds the limits of rational patterns in a fully comprehensive understanding of problems and search for numerous solutions [7]. Furthermore, the development of rational brain brings out of transmutation that enable people, specifical student to make conclusion (syllogism). Moreover, student with rational brain capability can carry out complicated measurement systematically performance by minimizing the subjectivity factor.

\section{b. Intuitive brain}

The intuitive brain or often named an imaginative mind [2] as the mental activity that is different from the rational brain in formal cognition thinking activities. Intuition is known as insight in Latin words which means depth-understanding (in-depth). Instead of perceiving, the intuitive brain works in-depth area towards implied meaning. The capability of the intuitive brain occurs outside of awareness (subconsciously [15]) without analytical processes as the affected of unique and anti-mainstream related to pattern recognition [8]. Intuitive brain access the information without the correlation of rational thinking [15] as the final stage of insight obtained from a period of incubation [16]. Furthermore, the typical type of this brain reached beyond the limitation, accidentally, and systematically, and a higher level of accuracy. According to Albert Einstein said that the rational brain is a faithful servant and the intuitive brain is a sacred gift. But, the society that has been created more honours the servant and forgotten the gift itself [17], [18] In fact, the social and educational environment more emphasized in the rational brain rather than intuitive brain as a noble gift.

Fishbein (1999) divided intuitively into two forms, which are affirmatory intuition (semantic-relational and individual) and anticipatory intuition (problem-solving). First, affirmatory intuition is intuition in form interpretations, reinterpretations [19], statements and the solution immediately emerges from individual. In the emanation approach, it belongs to prophets and messengers of the divine which is also known as revelation. Second, anticipatory intuition is an intuition that appears when an individual trying to work harder in problemsolving, but requires the long process and solution. In this case, anticipatory intuition is a general intuition that happens to anybody as human beings. In addition, the intuition between prophets (extraordinary), such as Prophet Khidr and Prophet Moses with the general individual (ordinary) has their own development in transmutation, specifically in the Islamic education perspective. The highest places of intuition are experienced by the 'holy individual', while the lowest of intuition is experienced scientists, scholars, or general person in their discoveries activities.

Regarding Al-Attas, the highest level of intuition also refers to the intuition that exists as the operation of the heart (qalb). In addition, the process of intellection and perception tends to the intuitive system, thereby the process of obtaining knowledge comes from rational activity that determines of truthness which is Revelation [20]. Meanwhile, someone who has the highest intuitive brain would like to be acceptance of truth based on religion, perceiving the existence of God. Moreover, the person connected to God through the spiritual experiences in various components that influence each other as the next step of neuroscience (neurotheology). The holistic function pushes humans to make a relation with divine power by relying on brain capability in any aspect, God must be there [21], [22]. The individual who has the rational brain only will not be able to be a religious person, even more skeptical outside 
their logic ways. The understanding of rational brain based on empiricism which bound by values (substance, causality, modality) and intuitive brain based on unconscious experiences (full of manner and essentials). The ability of intuitive brain can be shortcut jumper in understanding that becomes more effective and progressive without going through the systemic algorithm process. In other hand, intuition started to emerge from the point of limit from the five senses or rational brain as the end of the long journey in long-term processes of logical thinking. So, the transmutation from rational into intuitive levels of brain will be appearing when student has passed 'the exhausted of rationality' or the saturation point of creativity. The rational and the intuitive brain can be distinguished as follows:

Table 2. Disposition of rational and intuitive brain

\begin{tabular}{llll}
\hline Criteria & Rational brain & Intuitive brain \\
\hline $\begin{array}{l}\text { Emphasizing } \\
\text { Manifestation }\end{array}$ & $\begin{array}{l}\text { Concretization } \\
\text { Partiality and sequentially }\end{array}$ & $\begin{array}{l}\text { Abstraction } \\
\text { Globally } \\
\text { holistically } \\
\text { Linear }\end{array}$ \\
$\begin{array}{l}\text { Processing } \\
\text { information } \\
\text { Reality }\end{array}$ & Non-linear & and \\
Criteria & $\begin{array}{l}\text { Substance, causality, and } \\
\text { modality }\end{array}$ & Essentials \\
$\begin{array}{l}\text { Area } \\
\text { Aspect of intelligence }\end{array}$ & $\begin{array}{l}\text { Rational brain } \\
\text { Consciousness }\end{array}$ & Intuitive brain \\
\hline
\end{tabular}

\section{c. The Transmutation of Rational Brain into Intuitive Brain Based on Neuroscience}

In general education, the student's brain trained to make decisions based on their logic and empirical ways, whereas more emphasized in the left hemisphere of the brain. The affected of this system makes students in close-minded and limitation of thinking in conventional perpective. Therefore, it is needed the transmutation from rational into intuitive brains that can be produces the creative and imaginative brain. Intuition also established the decision-makers [23] which relevant to the education system, especially for student and teacher. Thus, to get high intuitive brain depends on the capability of the rational brain as mentioned before. The rational brain works in rationalization ways, while the intuitive brain works in concretization aspects. From a quality perspective, the left hemisphere and right hemisphere synergy produce the combination of a rational and intuitive approach that leads to better choices [24], in this case known as the intuitive brain. 


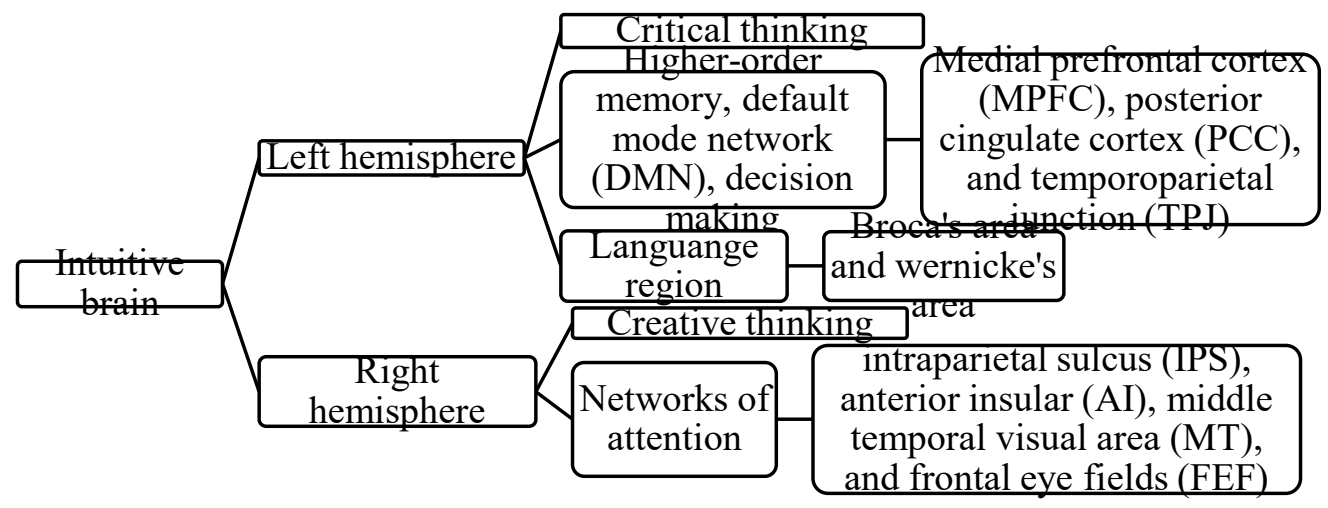

Figure 1. Transmutation of Intuitive Brain

The conditions for intuitive brain optimization between the prophets or messengers and ordinary humans have different treatments. It is misleading in Islamic education, when the Sufism and religious education want an understanding in the same level and took similar ways of emanations from the prophets and messengers. In fact, the substance to reach the intuitive brain in ordinary humans the exhausting step of rationality or saturation point and the prophets active "instantaneously" without requiring any condition. Our study analysis suggest the transmutation from rational into the intuitive brain in Islamic education occurs in two forms. First, provide assignments or questions that require analysis and synthesis for student. In this period, Islamic educators have only reached the student's comfort zone, such as memorizing and reading skills in standard regulations. The educators have to deal with saturation point by giving recitation that reaches out of the imaginative realms of student. According to Patton (2003), the educators as decision-makers can be used three sources of intuition that are general experience based on normal experience in daily life, innate respond based on subconscious pattern, and focused learning based on deliberate efforts [23]. These patterns construct of student's brains into intuitive working toward a specific goal and problem-solving. Second, the achievement of intuitive brain obtained by implemented the several highest taxonomy known as Higher Order Thinking Skills (HOTS), instead of LOTS (Lower Order Thinking Skills) by various experts. There are popular taxonomies in education, for example Bloom's Taxonomy [25], Revised Bloom's Taxonomy, Structure of Observed Learning Outcomes Taxonomy [26], [27], and Marzano Taxonomy [28].

Table 3. Taxonomies of Higher Order Thinking Skills

\begin{tabular}{llll}
\hline \multicolumn{1}{c}{$\begin{array}{c}\text { Bloom's } \\
\text { Taxonomy }\end{array}$} & $\begin{array}{c}\text { Revised Bloom's } \\
\text { Taxonomy }\end{array}$ & \multicolumn{1}{c}{$\begin{array}{c}\text { SOLO } \\
\text { Taxonomy }\end{array}$} & Marzano Taxonomy \\
\hline Analysis (C4) & Analysis (C4) & Multistructural & Knowledge utilization \\
Synthesis (C5) & Evaluation (C5) & Relational & Metacognitive system \\
Evaluation (C6) & Creation (C6) & Extended Abstract & Self-system \\
\hline
\end{tabular}

Therefore, the transmutation of Islamic education through an intuitive brain and its relevance to the story of Prophet Moses as and Prophet Khidr as has different treatments. If 
the prophets and messengers have reached the stage of "instant" emanation, while ordinary people need several stages even though their success cannot be equated with the prophets. Islamic education ideally applies a scientific process to achieve intuitive intelligence. In addition, the integration and interconnection between the natural, divine, and scientific realms will create a progressive Islamic education and make it a role model for both religious and academic circles. The implementation both of brain's side in the Islamic education that will bring out creative behavior of student as the highest expression of giftedness. It takes intention, earnest, and resignation to God. Consequently, Islamic education has to deal with the internalization of neuroscience, neurospiritual, and neurotheology in its curriculum so that understanding, thinking, and renewal are created with high efficiency and creativity.

\section{Conclusion}

Our review showed that the transmutation of intuitive brain transformed into two forms, which are the affirmatory intuition (emanation or revelation) and the anticipatory intuition (ordinary intuition). Emanation as the highest level of intuition occurs to prophets and messengers in directly process, while the anticipatory intuition occurs to a person wherein took several step-by-step and requires a processing system. The transmutation from rational into intuitive brain is obtained through exhausted point, specifically in Islamic education. The educator has to gain the knowledge within the bound of Higher Order Thinking Skills (HOTS) in taxonomies by experts (Bloom's Taxonomy, Revised Bloom's Taxonomy, SOLO Taxonomy, and Marzano Taxomony in commonly use. Finally, the transmutation will create a climate change in Islamic education in progressive and adaptive ways.

\section{References}

[1] L. Bakhtiar, Moses and Khidr Consciousness Between the Two Seas of Reason and Intuition Preface, no. August. Kazi Publications, 2019.

[2] Suyadi and H. Widodo, "Millennialization of Islamic Education Based on Neuroscience in The Third Generation University in Yogyakarta Indonesia," Qudus Int. J. Islam. Stud., vol. 7, no. 1, pp. 173-202, 2019.

[3] Suyadi and Sutrisno, "A Genealogycal Study of Islamic Education Science at The Faculty of Ilmu Tarbiyah dan Keguruan UIN Sunan Kalijaga,” Al-Jami'ah, vol. 56, no. 1, pp. 29-58, 2018.

[4] H. R. Haftador and E. H. Koohsari, "Examination of Human Psychological Needs according to Islamic Teachings," Asian Soc. Sci., vol. 11, no. 18, pp. 93-99, 2015.

[5] D. Yusmaliana and S. Suyadi, "Pengembangan Imajinasi Kreatif Berbasis Neurosains dalam Pembelajaran Keagamaan Islam," Edukasia J. Penelit. Pendidik. Islam, vol. 14, no. 2, p. 267, 2019.

[6] S. Suyadi, "Hybridization of Islamic Education and Neuroscience: Transdisciplinary Studies of 'Aql in the Quran and the Brain in Neuroscience," Din. Ilmu, vol. 19, no. 2, pp. 237-249, 2019.

[7] W. Hart, "Is It Rational or Intuitive? Factors and Processes Affecting School Superintendents' Decisions When Facing Professional Dilemmas.," Educ. Leadersh. Adm. Teach. Progr. Dev., vol. 29, no. 1, pp. 14-25, 2018. 
[8] C. Julmi, "When Rational Decision-Making Becomes Irrational: A Critical Assessment and Re-conceptualization of Intuition Effectiveness," Bus. Res., vol. 12, no. 1, pp. 291-314, 2019.

[9] A. Vaezipour, "Structure of Brain; Rationality and Intuition," Swedia, 2013.

[10] J. R. Đorđević, D. M. Pavlović, G. Mihajlović, and A. Pavlović, "Cerebral Hemispheres in Humans," Engrami, vol. 35, pp. 63-70, 2013.

[11] Y. Wang, S. Highhouse, C. J. Lake, N. L. Petersen, and T. B. Rada, "Meta-analytic Investigations of the Relation Between Intuition and Analysis," J. Behav. Decis. Mak., vol. 30, no. 1, pp. 15-25, 2017.

[12] A. Eastaugh, The Two Halves of The Brain, vol. 61, no. 592. London, England: The MIT Press, 2010.

[13] Suyadi, Sumaryati, D. Hastuti, and A. D. Saputro, "Early Childhood Education Teachers' Perception of The integration of Anti-Corruption Education into Islamic Religious Education in Bawean Island Indonesia," Elem. Educ. Online, vol. 19, no. 3, pp. 1703-1714, 2020.

[14] G. Calabretta, G. Gemser, and N. M. Wijnberg, "The Interplay between Intuition and Rationality in Strategic Decision Making: A Paradox Perspective," Organ. Stud., vol. 38, no. 3-4, pp. 365-401, 2017.

[15] J. Robinson, M. Sinclair, J. Tobias, and E. Choi, "More Dynamic Than You Think: Hidden Aspects of Decision-Making," Adm. Sci., vol. 7, no. 23, pp. 1-29, 2017.

[16] S. M. McCrea, "Intuition, Insight, and the Right Hemisphere: Emergence of Higher Sociocognitive Functions," Psychol. Res. Behav. Manag., vol. 3, pp. 1-39, 2010.

[17] R. P. Nalliah, "Clinical Decision Making - Choosing Between Intuition, Experience and Scientific Evidence," Br. Dent. J., vol. 221, no. 12, pp. 752-754, 2016.

[18] R. Leboon, "Rethinking Intuition: Using the Framework of an Integrative-Brain Assessment for Optimal Decision-Making," University of Pennsylvania, 2018.

[19] M. Ulpah, "Characteristics of Students' Intuitive Thinking in Solving Mathematical Problems," in International Conference of Moslem Society, 2019, vol. 3, pp. 48-57.

[20] A. F. Kamaruzaman, A. F. Omar, and R. Sidik, "Al-Attas' Philosophy of History on the Arrival and Proliferation of Islam in the Malay World," Int. J. Islam. Thought, vol. 10, no. 1, pp. 1-7, 2016.

[21] A. Sayadmansour, "Neurotheology: The Relationship Between Brain and Religion.," Iran. J. Neurol., vol. 13, no. 1, pp. 52-5, 2014.

[22] E. O. Hadinata, "The Brain As the Center of the Human Personality," Schema J. Psychol. Res., vol. 4, no. 2, pp. 1-10, 2018.

[23] A. M. Abubakar, H. Elrehail, M. A. Alatailat, and A. Elçi, "Knowledge Management, Decision-Making Style and Organizational Performance," J. Innov. Knowl., vol. 4, no. 2, pp. 104-114, 2019.

[24] K. Eling, F. Langerak, and A. Griffin, "The Performance Effects of Combining Rationality and Intuition in Making Early New Product Idea Evaluation Decisions," Creat. Innov. Manag., vol. 24, no. 3, pp. 464-477, 2015.

[25] S. R. Y. dan I. Lestari, "Higher-Order Thinking Skills (HOTS) Analysis of Students in Solving HOTS Question in Higher Education," Perspekt. Ilmu Pendidik., vol. 32, no. 2, pp. 181-188, 2018.

[26] A. L. Weay, M. Masood, S. Hawa, and Abdullah, "Systematic Review of Revised Bloom Taxonomy, SOLO Taxonomy and Webb's Depth of Knowledge (DOK) in Assessing Students' Historical Understanding in Learning History," Malaysian J. High. Order Think. Ski. Educ. Syst., no. October, pp. 1-27, 2016. 
[27] I. W. Widana, "Higher Order Thinking Skills Assessment (HOTS)," Jisae J. Indones. Student Assesment Eval., vol. 3, no. 1, pp. 32-44, 2017.

[28] R. J. Marzano and J. S. Kendall, Praise for the Second Edition of The New Taxonomy of Educational Objectives, Second Edi. Thousand Oaks, California: A SAGE Publications Company, 2007. 